\title{
EFFECT OF FORTIFICATION WITH WHEY PROTEIN ON THE CHEMICAL, MICROBIAL AND ORGANOLEPTICAL PROPERTIES OF LABNEH \\ Hamad, M. N. ${ }^{1 *}$, M. M. Ismail, ${ }^{2}$ and Monira, M. M. Basiony ${ }^{2}$ \\ 1 Department of Dairying, Faculty of Agriculture, Damietta University, Egypt. \\ 2 Dairy Technology Department, Animal Production Research Institute, Agricultural Research Center, Dokki, Giza, Egypt. \\ *Corresponding author email: mnour20002005@yahoo.com
}

\begin{abstract}
The aim of this study was to investigate the effects of incorporation of acid whey proteins (AWP) locally produced in Egypt on the chemical, microbial and organoleptical properties of Labneh made from goat's milk using ABT-5 culture. Five concentrations of AWP (5, 10, 15, 20 and 25\%) were added to Labneh paste and thoroughly mixed. Labneh was stored for 21 days at $5^{\circ} \mathrm{C}$ and samples were taken and analysed at 7 days intervals. The addition of AWP increased the of titratable acidity, redox potential, ash, salt, total protein, water soluble nitrogen, non-protein-nitrogen, total phenol contents and total volatile fatty acids. On contrary, $\mathrm{pH}$, total solids, fat and carbohydrate contents slightly decreased. Labneh contained AWP had higher numbers of $L$. acidophilus, S. thermophilus and B. bifidum. Scores of sensory evaluation of Labneh contained 5, 10 and 15\% AWP were similar to those of control, whereas sensory ratings and acceptability of Labneh decreased significantly by increasing AWP to 20 and $25 \%$. Addition of AWP reduced production cost of Labneh. Thus, numerous nutritional and economic benefits can be gained by fortifying Labneh with 5,10 and $15 \%$ AWP.

Keywords: ABT, Labneh, bifidobacteria, acid whey protein
\end{abstract}

\section{INTRODUCTION}

Labneh or strained/concentrated yogurt is a traditional fermented milk product. It is a popular food in various parts of the world especially in the Middle East (Syria, Lebanon, Jordan and Palestine). In recent years, the Labneh demand increased in Egypt because of the advent of many Syrians as a result of the war in Syria. Labneh is a white to creamy paste that has a smooth texture, with a taste crossing between sour cream and cottage cheese and a characteristic sharp flavor that is largely modulated by diacetyl produced during fermentation (Tamime and Robinson, 1999).

Over the past decade, considerable interest has developed in the use of probiotic organisms [Lactobacillus acidophilus (LA) and bifidobacteria] in food, pharmaceutical and feed products. The consumption of probiotic products has increased dramatically in most European. Asia-Pacific and American countries, and $>90$ products containing L. acidophilus, or bifidobacteria or both are available in the market worldwide (Parmar 2003). The other key component of probiotic products is prebiotic ingredient. Prebiotics are food ingredients that beneficially affect the host by selectively stimulating the growth and/or activity of one or a limited number of bacteria in 
colon that can improve the host health (Niness 1999). When prebiotics are used in combination with probiotics or live bacteria, the resultant has synergistic effects, referred to as "synbiotic". This is because in addition to the action of probiotics that promote the growth of existing strains of beneficial bacteria in the colon, prebiotics also act to improve the survival, implantation and growth of newly added probiotics strains.

On the other hand, whey protein is a by-product of the cheese industry. It is often referred to as the "Gold Standard" of protein as it is the most nutritious protein available and is a low-cost source of protein (Belobrajdic et al., 2004). There are considerable data on the use of sweet whey and its derivatives in fermented foods but literature on the feasibility of incorporation of acid whey solids in it is in scant. However, to exploit the benefits of small peptides and amino acids present in acid whey, it is vital to find a way to incorporate acid whey into yogurt formulations because these nitrogenous substances could have growth promoting effects on probiotic organisms (Parmar 2003). Ravula and Shah (1999) have recommended incorporation of one or other forms of nitrogenous substances or amino acids to enhance the growth and viability of probiotics. So the objectives of the present work were to 1) investigate the possibility of using acid whey proteins as a prebiotic and 2) reduce the production cost of bio-Labneh.

\section{MATERIALS AND METHODS}

ABT culture (ABT-5) with mixed strains of $S$. thermophilus (as sole fermenting organism) and LA $+B$. bifidum (as probiotic organisms) (Chr. Hansen's Lab A/S Copenhagen, Denmark) was used. Starter culture was in freeze-dried direct-to-vat set form. After procurement, the starter cultures were stored at $-18^{\circ} \mathrm{C}$ in the absence of atmospheric air. Fresh morning goat's milk (acidity $0.17 \%$, pH 6.61, fat 4.6 , TS 13.11 and total protein $3.56 \%$ ) was obtained from El-Serw Animal Production Research Station, Animal Production Research Institute, Agricultural Research Center, Egypt.

Ras cheese whey ( $\mathrm{pH}$ 5.91) was heated to $85^{\circ} \mathrm{C}$ for 10 min., cooled and the flocculated denatured whey proteins were recovered by straining through cloth bags for three hrs. The precipitate was transferred to wooden frames and pressed overnight. The resultant acid whey protein past has $0.27 \%$ acidity, $5.39 \mathrm{pH}, 23.1 \%$ total solids, $0.7 \%$ fat, $15.1 \%$ total protein, $7.26 \%$ ash and $6.35 \%$ salt.

Labneh was made using the procedure normally used in homes. Fresh goat's milk was heated to $90^{\circ} \mathrm{C}$ for $10 \mathrm{~min}$., cooled to $40^{\circ} \mathrm{C}$, inoculated with ABT- 5 culture $\left(0.1 \mathrm{~g} / \mathrm{L}\right.$ of yoghurt) and incubated at $40^{\circ} \mathrm{C}$ for fully coagulation. The produced yoghurt was left at $4^{\circ} \mathrm{C}$ overnight, mixed and put into cloth bags which were hung for $24 \mathrm{~h}$ in a refrigerator to allow for whey drainage. The resulting Labneh was mixed with $1 \%$ salt $(\mathrm{NaCl})$. Five concentrations of acid whey protein paste $(5,10,15,20$ and $25 \%$ ) were added to Labneh and strongly blended. The mixture of Labneh and AWP transferred to $250 \mathrm{~g}$ plastic cups, covered with polyethylene film and stored at $5^{\circ} \mathrm{C}$ for 21 days. Labneh 
samples were analyzed when fresh and after 7, 14 and 21 days of refrigerated storage. Three replicates of each treatment were conducted.

Total solids, fat, TN and ash contents of samples were determined according to (AOAC, 2000). Titratable acidity in terms of \% lactic acid was measured by titrating $10 \mathrm{~g}$ of sample mixed with $10 \mathrm{ml}$ of boiling water by 0.1 $\mathrm{N} \mathrm{NaOH}$ in the presence phenolphthalein indicator to an end point of faint pink color (Parmar 2003). pH of the sample was measured using a $\mathrm{pH}$ meter (Corning $\mathrm{pH} /$ ion analyzer 350 , Corning, NY) after calibration with standard buffers ( $\mathrm{pH} 4.0$ and 7.0). Water soluble nitrogen (WSN) and non-proteinnitrogen (NPN) of Labneh were estimated according to Ling (1963). Total volatile fatty acids (TVFA) were determined according to Kosikowiski (1978). Salt contents of ingredients were estimated using Volhard method according to Richardson (1985). The method of Zheng and Wang (2001) was followed in determining the total phenol compounds in Labneh using Folin Ciocalteu Reagent (FCR) and gallic acid as a standard solution. Total carbohydrates were calculated by difference as described by Ceirwyn (1995).

Labneh samples were analyzed for total viable bacterial count (TVBC), $L$. acidophilus, $S$. thermophilus, moulds and yeast counts according to the methods described by the American Public Health Association (1992). The count of bifidobacteria was determined according to Dinakar and Mistry (1994). A mixture of antibiotics, including $2 \mathrm{~g}$ of neomycin sulfate, $4 \mathrm{~g}$ of paromomycin sulfate, $0.3 \mathrm{~g}$ of nalidixic acid, and $60 \mathrm{~g}$ of lithium chloride (NPNL, Sigma Chemical Co.), was prepared in $1 \mathrm{~L}$ of distilled water, filtersterilized $(.22 \mathrm{pm})$, and stored at $4^{\circ} \mathrm{C}$ until use. The mixture of antibiotics $(5$ $\mathrm{ml}$ ) was added to $100 \mathrm{ml}$ of MRS agar medium. Cysteine-HC1 was added at the rate of $0.05 \%$ to decrease the redox potential of the medium. Plates were incubated at $37^{\circ} \mathrm{C}$ for 48 to $72 \mathrm{~h}$ under anaerobic condition.

Samples of Labneh were organoleptically scored by the staff of the ElSerw Animal Production Research Station. The score points were 50 for flavour, 35 for body and texture and 15 for colour and appearance, which give a total score of 100 points.

The obtained results were statistically analyzed using a software package (SAS, 1991) based on analysis of variance. When F-test was significant, least significant difference (LSD) was calculated according to Duncan (1955) for the comparison between means. The data presented, in the tables, are the mean ( \pm standard deviation) of 3 experiments.

\section{RESULTS AND DISCUSSION}

\section{Changes in chemical composition of Labneh during refrigerated storage for 21 days}

Results shown in Table 1 represent the effect of incorporation various levels of AWP on the titratable acidity (\% lactic acid), $\mathrm{pH}$, redox potential of and total solids (TS) contents of Labneh during the refrigerated storage. It could be seen from Table 1 that Labneh made using of AWP (samples B, C, $D, E$ and $F$ ) was relatively more acidic, compared to that made without addition of AWP (treatment A). Of coarse, this attributed to the acidity of whey 
protein. These results are confirmed with the previous results reported by Tashakori et al., (2013) who found that the control white Feta cheese sample had the lowest acidity and highest $\mathrm{pH}$, and the sample with $1.5 \%$ whey protein concentrate had the highest acidity and lowest $\mathrm{pH}$. Also, blending of AWP with Labneh paste increased $E_{h}$ values. On the other hand, incorporation of AWP slightly decreased TS content of the produced Labneh. This might be due to the high water holding capacity of whey proteins, which may increase the moisture holding in curd (Ismail, 2012).

Table 1 Effect of adding of AWP to goat's milk on some physicochemical properties of Labneh (means \pm SD)

\begin{tabular}{|c|c|c|c|c|c|c|}
\hline \multirow{2}{*}{ Properties } & \multirow{2}{*}{ Treatments } & \multicolumn{4}{|c|}{ Storage period (day) } & \multirow{2}{*}{$\begin{array}{c}\text { Means } \pm \\
\text { SD }\end{array}$} \\
\hline & & 1 & 7 & 14 & 21 & \\
\hline \multirow{7}{*}{$\begin{array}{l}\text { Acidity } \\
\%\end{array}$} & A & 1.38 & 1.44 & 1.51 & 1.61 & $1.485^{\mathrm{d}}$ \\
\hline & $\mathrm{B}$ & 1.41 & 1.49 & 1.58 & 1.69 & $1.542^{\mathrm{C}}$ \\
\hline & $\mathrm{C}$ & 1.45 & 1.54 & 1.63 & 1.74 & $1.590^{\mathrm{C}}$ \\
\hline & $\mathrm{D}$ & 1.48 & 1.59 & 1.70 & 1.80 & $1.642^{\mathrm{b}}$ \\
\hline & $\mathrm{E}$ & 1.52 & 1.64 & 1.78 & 1.87 & $1.702^{\mathrm{a}}$ \\
\hline & $\mathrm{F}$ & 1.58 & 1.70 & 1.84 & 1.96 & $1.770^{\mathrm{a}}$ \\
\hline & Means \pm SD & $1.473^{\mathrm{D}}$ & $1.567^{C}$ & $1.673^{\mathrm{B}}$ & $1.778^{A}$ & \\
\hline \multirow{7}{*}{$\begin{array}{l}\mathrm{pH} \\
\text { values }\end{array}$} & $A$ & 4.67 & 4.54 & 4.44 & 4.23 & $4.471^{\mathrm{a}}$ \\
\hline & B & 4.62 & 4.49 & 4.30 & 4.14 & $4.387^{\mathrm{b}}$ \\
\hline & $\mathrm{C}$ & 4.56 & 4.38 & 4.19 & 4.08 & $4.302^{\mathrm{c}}$ \\
\hline & D & 4.49 & 4.29 & 4.12 & 3.97 & $4.217^{d}$ \\
\hline & $\mathrm{E}$ & 4.40 & 4.20 & 4.04 & 3.85 & $4.122^{\mathrm{e}}$ \\
\hline & $\mathrm{F}$ & 4.32 & 4.13 & 3.93 & 3.74 & $4.030^{\mathrm{e}}$ \\
\hline & Means \pm SD & $4.510^{A}$ & $4.338^{\mathrm{B}}$ & $4.170^{C}$ & $4.002^{\mathrm{D}}$ & \\
\hline \multirow{7}{*}{$\begin{array}{l}\mathrm{E}_{\mathrm{h}} \\
\mathrm{mV}\end{array}$} & $A$ & 112.4 & 121.3 & 135.9 & 156.2 & $131.45^{\dagger}$ \\
\hline & B & 118.6 & 125.2 & 142.3 & 163.1 & $137.30^{\mathrm{e}}$ \\
\hline & C & 121.3 & 129.7 & 146.1 & 169.2 & $141.57^{d}$ \\
\hline & $\mathrm{D}$ & 126.7 & 137.1 & 156.7 & 177.3 & $149.45^{c}$ \\
\hline & $\mathrm{E}$ & 133.2 & 145.4 & 166.4 & 189.4 & $158.60^{b}$ \\
\hline & $\mathrm{F}$ & 137.1 & 150.5 & 174.4 & 198.7 & $165.17^{\mathrm{a}}$ \\
\hline & Means \pm SD & $124.88^{\mathrm{D}}$ & $134.87^{C}$ & $153.63^{B}$ & $175.65^{A}$ & \\
\hline \multirow{7}{*}{$\begin{array}{l}\text { TS } \\
\%\end{array}$} & $\mathrm{~A}$ & 26.48 & 26.61 & 26.75 & 26.94 & $26.695^{\mathrm{a}}$ \\
\hline & B & 26.32 & 26.46 & 26.61 & 26.73 & $26.530^{\mathrm{ab}}$ \\
\hline & $\mathrm{C}$ & 26.15 & 26.28 & 26.43 & 26.54 & $26.350^{b}$ \\
\hline & D & 25.97 & 26.17 & 26.31 & 26.45 & $26.225^{c}$ \\
\hline & E & 25.79 & 25.94 & 26.19 & 26.30 & $26.055^{d}$ \\
\hline & $\mathrm{F}$ & 25.55 & 25.70 & 25.83 & 25.95 & $25.757^{e}$ \\
\hline & Means \pm SD & $26.043^{\mathrm{C}}$ & $26.193^{B}$ & $26.353^{A}$ & $26.269^{B}$ & \\
\hline
\end{tabular}

abcde Letters indicate significant differences between Labneh treatments

$A B C D$ Letters indicate significant differences between storage times

A- Labneh control

B- Labneh control + 5\% AWP

C- Labneh control + 10\% AWP

D- Labneh control + 15\% AWP

E- Labneh control + $20 \%$ AWP

F- Labneh control + 25\%AWP

As storage period advanced, the acidity, $E_{h}$ and TS values of Labneh in all treatments increased gradually, while $\mathrm{pH}$ values significantly decreased $(\mathrm{P}<0.001)$. Increase of the acidity and decease of the $\mathrm{pH}$ values may be due to the fermentation of lactose to lactic acid. Similar results were found by Salem et al., (2013). Abbas and Osman (1998) reported that the titratable acidity increased gradually during storage period of Labneh. Moreover, Mahdian and Tehrani (2007) discovered that high total solids content improved the growth and activity of starter cultures and increased acidity. 
Morris (2000) reported that $E_{h}$ of a growth medium has an inverse relationship with $\mathrm{pH}$. Therefore, this increase in yogurt $\mathrm{E}_{\mathrm{h}}$ from day 1 to 15 could be attributed to the decrease in $\mathrm{pH}$ during the same storage period and/or increase in oxygen tension due to air permeability through the plastic containers during storage.

As total solids of Labneh decreased to addition of AWP, fat and carbohydrate contents also decreased (Table 2). Rreverse this trend, significant increases in total protein and ash contents were obtained with the incorporation of AWP in Labneh, which was positive proportion with the concentrations added of AWP. Because of acid whey protein added to Labneh paste contained salt, it was normal that the salt content significantly increased in mixture of Labneh and AWP. The highest ratios of salt at zero time and at the end of storage period were found in Labneh made using $25 \%$ AWP being 2.09 and $2.20 \%$, respectively. Punidadas et al., (2007) showed that adding whey proteins improved the yield, but lowered the retention of fat. Homogenization of whey proteins improved fat retention and yield. The dry matter increase was due to increased SNF.

Table 2 Effect of adding of AWP to goat's milk on chemical composition of Labneh (means $\pm \mathrm{SD}$ )*

\begin{tabular}{|c|c|c|c|c|c|c|}
\hline \multirow{2}{*}{ Properties } & \multirow{2}{*}{ Treatments } & \multicolumn{4}{|c|}{ Storage period (day) } & \multirow{2}{*}{$\begin{array}{c}\text { Means } \pm \\
\text { SD }\end{array}$} \\
\hline & & 1 & 7 & 14 & 21 & \\
\hline \multirow{7}{*}{$\begin{array}{l}\text { Fat } \\
\%\end{array}$} & A & 10.7 & 10.8 & 10.9 & 11.1 & $10.875^{\mathrm{a}}$ \\
\hline & $\mathrm{B}$ & 10.6 & 10.7 & 10.8 & 10.9 & $10.750^{b}$ \\
\hline & $\mathrm{C}$ & 10.6 & 10.7 & 10.8 & 10.9 & $10.750^{b}$ \\
\hline & $\mathrm{D}$ & 10.5 & 10.6 & 10.7 & 10.8 & $10.650^{b}$ \\
\hline & $\mathrm{E}$ & 10.3 & 10.4 & 10.6 & 10.7 & $10.500^{c}$ \\
\hline & $\mathrm{F}$ & 10.2 & 10.3 & 10.4 & 10.5 & $10.350^{d}$ \\
\hline & Means \pm SD & $10.483^{D}$ & $10.583^{C}$ & $10.700^{\mathrm{B}}$ & $10.817^{A}$ & \\
\hline \multirow{7}{*}{$\begin{array}{l}\text { Carbohydrate } \\
\%\end{array}$} & A & 4.78 & 4.63 & 4.51 & 4.32 & $4.560^{\mathrm{a}}$ \\
\hline & B & 4.25 & 4.05 & 3.95 & 3.79 & $4.010^{\mathrm{b}}$ \\
\hline & $\mathrm{C}$ & 3.59 & 3.46 & 3.33 & 3.19 & $3.392^{c}$ \\
\hline & D & 3.01 & 2.96 & 2.91 & 2.69 & $2.892^{d}$ \\
\hline & $\mathrm{E}$ & 2.38 & 2.28 & 2.17 & 1.98 & $2.202^{\mathrm{e}}$ \\
\hline & $\mathrm{F}$ & 1.70 & 1.59 & 1.44 & 1.26 & $1.497^{\dagger}$ \\
\hline & Means \pm SD & $3.285^{A}$ & $3.162^{\mathrm{B}}$ & $3.052^{c}$ & $2.872^{\mathrm{D}}$ & \\
\hline \multirow{7}{*}{$\begin{array}{l}\text { Total Protein } \\
\%\end{array}$} & $\mathrm{~A}$ & 9.15 & 9.24 & 9.33 & 9.41 & $9.282^{\dagger}$ \\
\hline & B & 9.46 & 9.56 & 9.62 & 9.70 & $9.585^{\mathrm{e}}$ \\
\hline & $\mathrm{C}$ & 9.69 & 9.75 & 9.82 & 9.88 & $9.785^{d}$ \\
\hline & D & 9.94 & 10.01 & 10.09 & 10.16 & $10.050^{c}$ \\
\hline & $\mathrm{E}$ & 10.33 & 10.40 & 10.47 & 10.57 & $10.442^{b}$ \\
\hline & $\mathrm{F}$ & 10.66 & 10.74 & 10.84 & 10.95 & $10.797^{a}$ \\
\hline & Means \pm SD & $9.872^{\mathrm{D}}$ & $9.950^{C}$ & $10.028^{B}$ & $10.112^{\mathrm{A}}$ & \\
\hline \multirow{7}{*}{$\begin{array}{l}\text { Ash } \\
\%\end{array}$} & $\mathrm{~A}$ & 1.85 & 1.93 & 2.01 & 2.11 & $1.975^{\dagger}$ \\
\hline & B & 2.01 & 2.15 & 2.24 & 2.34 & $2.185^{\mathrm{e}}$ \\
\hline & $\mathrm{C}$ & 2.27 & 2.37 & 2.48 & 2.57 & $2.422^{d}$ \\
\hline & D & 2.52 & 2.60 & 2.71 & 2.80 & $2.657^{\mathrm{c}}$ \\
\hline & $E$ & 2.78 & 2.86 & 2.95 & 3.05 & $2.910^{\mathrm{b}}$ \\
\hline & $\bar{F}$ & 2.99 & 3.07 & 3.15 & 3.24 & $3.112^{a}$ \\
\hline & Means \pm SD & $2.403^{\mathrm{C}}$ & $2.500^{B}$ & $2.585^{\mathrm{AB}}$ & $2.685^{A}$ & \\
\hline \multirow{7}{*}{$\begin{array}{l}\text { Salt } \\
\%\end{array}$} & A & 0.93 & 0.96 & 0.98 & 0.99 & $0.965^{\dagger}$ \\
\hline & B & 1.15 & 1.16 & 1.19 & 1.23 & $1.182^{\mathrm{e}}$ \\
\hline & C & 1.34 & 1.37 & 1.39 & 1.40 & $1.375^{\mathrm{d}}$ \\
\hline & D & 1.60 & 1.64 & 1.68 & 1.70 & $1.655^{\mathrm{c}}$ \\
\hline & $\mathrm{E}$ & 1.88 & 1.90 & 1.93 & 1.96 & $1.917^{\mathrm{b}}$ \\
\hline & $\bar{F}$ & 2.09 & 2.12 & 2.17 & 2.20 & $2.145^{\mathrm{a}}$ \\
\hline & Means \pm SD & $1.498^{\mathrm{B}}$ & $1.525^{\mathrm{AB}}$ & $1.577^{A}$ & $1.580^{A}$ & \\
\hline
\end{tabular}

abcde Letters indicate significant differences between Labneh treatments

${ }^{A B C D}$ Letters indicate significant differences between storage times ${ }^{*}$ See Table 1 
During storage, fat, total protein, ash and salt contents of various Labneh samples slightly increased and could be ascribed to moisture loss (Al.Otaibi and El.Demerdash 2008). Conversely, carbohydrate content gradually decreased.

Results of water soluble nitrogen (WSN), non-protein-nitrogen (NPN), total phenol and TVFA values of Labneh are shown in Table 3. Addition of AWP increased WSN, NPN, total phenol and TVFA contents of Labneh, and the rates of increasing were proportional with the amount added. Similar results were found by Ismail et al.,(2011) who showed that the incorporation of whey protein with buffaloe's milk increased the TVFA content of the resultant Mozzarella cheese. This might be due to more moisture was retained in cheese by adding whey protein which enhanced lipolysis.

During refrigerated storage, WSN, NPN and TVFA contents significantly increased, and the increasing rates were higher in Labneh treated with AWP as compared with control. Increasing of WSN and NPN content might be due to the protein breakdown in the Labneh by milk enzymes and other microbial activities (El-Zeini et al., 2007). On the contrary, total phenols content gradually lowered within the storage period.

Table 3 Effect of adding of AWP to goat's milk on WSN, NPN, total phenols and TVFA contents of Labneh (means \pm SD) ${ }^{\star}$

\begin{tabular}{|c|c|c|c|c|c|c|}
\hline \multirow{2}{*}{ Properties } & \multirow{2}{*}{ Treatments } & \multicolumn{4}{|c|}{ Storage period (day) } & \multirow{2}{*}{$\begin{array}{c}\text { Means } \pm \\
\text { SD }\end{array}$} \\
\hline & & 1 & 7 & 14 & 21 & \\
\hline \multirow{7}{*}{$\begin{array}{l}\text { WSN } \\
\%\end{array}$} & $\bar{A}$ & 0.314 & 0.348 & 0.387 & 0.445 & $0.373^{\mathrm{e}}$ \\
\hline & $\mathrm{B}$ & 0.329 & 0.364 & 0.411 & 0.460 & $0.391^{d}$ \\
\hline & $\mathrm{C}$ & 0.347 & 0.390 & 0.454 & 0.523 & $0.428^{\mathrm{C}}$ \\
\hline & $\mathrm{D}$ & 0.366 & 0.419 & 0.466 & 0.539 & $0.447^{b}$ \\
\hline & $\mathrm{E}$ & 0.381 & 0.434 & 0.487 & 0.561 & $0.466^{\mathrm{a}}$ \\
\hline & $\mathrm{F}$ & 0.395 & 0.452 & 0.519 & 0.574 & $0.485^{\mathrm{a}}$ \\
\hline & Means \pm SD & $0.355^{\mathrm{D}}$ & $0.402^{C}$ & $0.454^{\mathrm{B}}$ & $0.517^{A}$ & \\
\hline \multirow{7}{*}{$\begin{array}{l}\text { NPN } \\
\%\end{array}$} & $\mathrm{~A}$ & 0.122 & 0.147 & 0.177 & 0.215 & $0.165^{\dagger}$ \\
\hline & B & 0.145 & 0.176 & 0.211 & 0.254 & $0.196^{\mathrm{e}}$ \\
\hline & $\mathrm{C}$ & 0.168 & 0.199 & 0.239 & 0.288 & $0.223^{d}$ \\
\hline & $\mathrm{D}$ & 0.194 & 0.234 & 0.268 & 0.324 & $0.255^{\mathrm{C}}$ \\
\hline & $\mathrm{E}$ & 0.229 & 0.257 & 0.291 & 0.347 & $0.281^{\mathrm{b}}$ \\
\hline & $\mathrm{F}$ & 0.257 & 0.291 & 0.344 & 0.392 & $0.321^{a}$ \\
\hline & Means \pm SD & $0.186^{\mathrm{D}}$ & $0.217^{C}$ & $0.225^{\mathrm{B}}$ & $0.303^{A}$ & \\
\hline \multirow{7}{*}{$\begin{array}{l}\text { Total phenols } \\
\mathrm{Mg} / 100 \mathrm{~g}\end{array}$} & $A$ & 34.16 & 32.85 & 30.25 & 28.16 & $31.355^{\dagger}$ \\
\hline & B & 35.78 & 33.41 & 31.04 & 30.02 & $32.562^{e}$ \\
\hline & C & 37.12 & 36.10 & 33.56 & 31.43 & $34.552^{d}$ \\
\hline & D & 38.69 & 36.83 & 33.89 & 30.87 & $35.070^{c}$ \\
\hline & $E$ & 40.82 & 37.87 & 35.12 & 33.13 & $36.735^{b}$ \\
\hline & $\mathrm{F}$ & 43.74 & 41.50 & 39.08 & 36.75 & $40.267^{\mathrm{a}}$ \\
\hline & Means \pm SD & $38.385^{A}$ & $36.427^{B}$ & $33.823^{C}$ & $31.727^{D}$ & \\
\hline \multirow{7}{*}{ TVFA** } & A & 10.00 & 11.54 & 12.66 & 14.28 & $12.120^{\mathrm{e}}$ \\
\hline & B & 10.24 & 11.84 & 13.04 & 15.62 & $12.685^{d}$ \\
\hline & $\mathrm{C}$ & 10.62 & 12.14 & 13.38 & 15.88 & $13.005^{c}$ \\
\hline & D & 10.88 & 12.34 & 13.78 & 16.30 & $13.325^{b}$ \\
\hline & $E$ & 10.96 & 12.60 & 13.98 & 16.52 & $13.515^{\mathrm{a}}$ \\
\hline & $\mathrm{F}$ & 11.04 & 12.96 & 14.24 & 16.88 & $13.780^{a}$ \\
\hline & Means \pm SD & $10.623^{D}$ & $12.237^{C}$ & $13.513^{B}$ & $15.913^{A}$ & \\
\hline
\end{tabular}

abcde Letters indicate significant differences between Labneh treatments

${ }^{A B C D}$ Letters indicate significant differences between storage times

* See Table 1

** expressed as $\mathrm{ml} 0.1 \mathrm{NaOH} 100 \mathrm{~g}^{-1}$ cheese 


\section{Changes in microbial counts of Labneh during refrigerated storage for 21 days}

The effects of adding acid whey protein to Labneh on the total viable bacterial counts (TVBC) and the viable counts of $L$. acidophilus, $S$. thermophilus, bifidobacteria, moulds and yeasts were illustrated in Table 4. No moulds and yeasts growth was detected in different fresh Labneh treatments, but they appeared after 7 days and increased till the end of storage. Also, TVBC for all samples increased through out refrigerated storage, while numbers of $L$. acidophilus, $S$. thermophilus and bifidobacteria gradually lowered during storage of Labneh. This reduction in the counts of the different microorganisms might be attributed to the high acidity produced by microbial fermentation (Dave and Shah, 1997). On the other side, significantly $(p<0.001)$ increases were observed in the viable number of the above mentioned microbial groups in Labneh mixed with AWP. These results refer to the enrichment of dairy products like (Labneh) with whey protein which enhances the activity of probiotic organisms. Baig and Prasad (1996) stated that improvement in the growth of probiotic organisms have been reported with incorporation of cottage cheese whey solids in yogurt mix and using whey based medium. Since cottage cheese whey is believed to be rich in small peptides and free amino acids, incorporation of solids derived from it could have a significant effect on improvement of the viability of probiotic bacteria and starter performance in yogurt. Additionally, it could also reduce environmental concerns lower production cost and improve the functional properties of fermented products., Dave and Shah (1998) Also observed that the viability of probiotic bacteria in commercial starter culture could be improved upon fortification of yogurt mixes with whey protein concentrate. They concluded that the protein break down products and intermediate peptides might have improved the growth of probiotics.

However, the drop in the probiotic bacteria counts during storage time, although remained above $10^{6} \mathrm{cfu} . \mathrm{g}^{-1}$ in all Labneh samples. This means that the viability of strains after the storage period was sufficient to yield numbers of beneficial organisms that were higher than the accepted threshold $\left(10^{6} \mathrm{cfu}^{-1} \mathrm{~g}^{-1}\right.$ for a probiotic effect (Gomes and Malcata 1998). One of the possibilities of high stability of bifidobacteria at refrigerated storage in these samples could be the absence of $L b$. delbrueckii ssp. bulgaricus which is known to produce post acidification. Post acidification could have further inhibitory effect on the $S$. thermophilus counts. 
Table 4 Effect of adding of AWP to goat's milk on some microbial groups of Labneh*

\begin{tabular}{|c|c|c|c|c|c|c|}
\hline \multirow{2}{*}{ Properties } & \multirow{2}{*}{ Treatments } & \multicolumn{4}{|c|}{ Storage period (day) } & \multirow{2}{*}{ Means \pm SD } \\
\hline & & 1 & 7 & 14 & 21 & \\
\hline \multirow{7}{*}{$\begin{array}{l}\text { TVBC } \\
\left(x 10^{6}\right)\end{array}$} & $A$ & 135 & 147 & 165 & 180 & $156.75^{\dagger}$ \\
\hline & B & 141 & 150 & 170 & 186 & $161.75^{\mathrm{e}}$ \\
\hline & $\mathrm{C}$ & 143 & 153 & 174 & 189 & $164.75^{d}$ \\
\hline & $\mathrm{D}$ & 144 & 155 & 179 & 194 & $168.00^{c}$ \\
\hline & $E$ & 146 & 158 & 182 & 199 & $171.25^{\mathrm{b}}$ \\
\hline & $\mathrm{F}$ & 149 & 161 & 187 & 207 & $176.00^{\mathrm{a}}$ \\
\hline & Means \pm SD & $143.00^{D}$ & $154.00^{C}$ & $176.17^{\mathrm{B}}$ & $192.50^{A}$ & \\
\hline \multirow{7}{*}{$\begin{array}{l}\text { L. acidophilus } \\
\left(\times 10^{5}\right)\end{array}$} & $A$ & 34 & 30 & 27 & 23 & $28.50^{\dagger}$ \\
\hline & $B$ & 37 & 35 & 33 & 30 & $33.75^{\mathrm{e}}$ \\
\hline & C & 38 & 35 & 32 & 30 & $33.75^{d}$ \\
\hline & $\mathrm{D}$ & 42 & 41 & 40 & 37 & $40.00^{c}$ \\
\hline & $E$ & 44 & 43 & 42 & 38 & $41.75^{b}$ \\
\hline & $\mathrm{F}$ & 45 & 44 & 42 & 39 & $42.50^{a}$ \\
\hline & Means \pm SD & $40.00^{A}$ & $38.00^{\mathrm{B}}$ & $36.00^{C}$ & $32.83^{D}$ & \\
\hline \multirow{7}{*}{$\begin{array}{l}\text { S. } \\
\text { thermophilus } \\
\left(\times 10^{5}\right)\end{array}$} & $A$ & 45 & 43 & 40 & 36 & $41.00^{\dagger}$ \\
\hline & B & 46 & 43 & 41 & 34 & $41.00^{\mathrm{e}}$ \\
\hline & C & 48 & 47 & 45 & 41 & $45.25^{d}$ \\
\hline & D & 51 & 49 & 46 & 41 & $46.75^{c}$ \\
\hline & $E$ & 52 & 48 & 46 & 42 & $47.00^{b}$ \\
\hline & $\mathrm{F}$ & 55 & 52 & 50 & 46 & $50.75^{a}$ \\
\hline & Means \pm SD & $49.50^{A}$ & $47.00^{B}$ & $44.67^{\mathrm{C}}$ & $40.00^{D}$ & \\
\hline \multirow{7}{*}{$\begin{array}{l}\text { Bifidobacteria } \\
\left(\times 10^{5}\right)\end{array}$} & $A$ & 23 & 21 & 20 & 16 & $20.00^{\dagger}$ \\
\hline & B & 26 & 23 & 21 & 18 & $22.00^{\mathrm{e}}$ \\
\hline & C & 28 & 26 & 24 & 20 & $24.50^{d}$ \\
\hline & D & 29 & 26 & 23 & 20 & $24.50^{c}$ \\
\hline & $E$ & 31 & 29 & 28 & 23 & $27.75^{b}$ \\
\hline & $\mathrm{F}$ & 35 & 33 & 30 & 25 & $30.75^{a}$ \\
\hline & Means \pm SD & $28.67^{A}$ & $26.33^{\mathrm{B}}$ & $24.33^{C}$ & $20.33^{D}$ & \\
\hline \multirow{7}{*}{$\begin{array}{l}\text { Moulds \& Yeast } \\
\left(x 10^{3}\right)\end{array}$} & $A$ & ND & 2 & 5 & 13 & $5.00^{\dagger}$ \\
\hline & $B$ & ND & 2 & 6 & 14 & $5.50^{e}$ \\
\hline & C & ND & 3 & 6 & 16 & $6.25^{d}$ \\
\hline & D & ND & 2 & 7 & 18 & $6.75^{c}$ \\
\hline & $E$ & ND & 4 & 7 & 22 & $8.25^{b}$ \\
\hline & $\mathrm{F}$ & ND & 5 & 9 & 26 & $10.00^{\mathrm{a}}$ \\
\hline & Means \pm SD & - & $3.00^{C}$ & $6.67^{B}$ & $18.17^{A}$ & \\
\hline
\end{tabular}

\section{Changes in sensory evaluation of Labneh during refrigerated storage for 21 days}

The results given in Table 5 described the influence of addition of acid whey protein on the organoleptic properties of Labneh. Scores of color and appearance of control and Labneh contained 5, 10 and 15\% AWP were similar while by increasing of AWP ratios to 20 and $25 \%$ resulted in decrease the sensory evaluation of color and appearance in fresh and stored Labneh. Treatment B (5\% AWP) gained the highest scores of body, texture and flavour. Addition of 10 and $15 \%$ AWP to Labneh past had no clear effect on the properties of body, texture and flavour but with high incorporation levels (20 and 25\%) these scores lowered as compared with control. Ismail (2012) reported that addition of whey proteins to milk or curd slightly raised scores of 
organoleptic properties of Ras cheese. However, at the end of ripening periods (120 days) samples made by mixing curd with 1 and $2 \%$ whey proteins gained the lowest scores.

Table 5 Effect of adding of AWP to goat's milk on organoleptic properties of Labneh*

\begin{tabular}{|c|c|c|c|c|c|c|}
\hline \multirow{2}{*}{ Properties } & \multirow{2}{*}{ Treatments } & \multicolumn{4}{|c|}{ Storage period (day) } & \multirow{2}{*}{$\begin{array}{c}\text { Means } \pm \\
\text { SD }\end{array}$} \\
\hline & & 1 & 7 & 14 & 21 & \\
\hline \multirow{7}{*}{$\begin{array}{c}\text { Color\& } \\
\text { Appearance } \\
(15)\end{array}$} & $A$ & 14 & 13 & 12 & 11 & $12.50^{\mathrm{a}}$ \\
\hline & B & 14 & 13 & 12 & 11 & $12.50^{\mathrm{a}}$ \\
\hline & $\mathrm{C}$ & 14 & 13 & 12 & 11 & $12.50^{\mathrm{a}}$ \\
\hline & $\mathrm{D}$ & 14 & 13 & 12 & 10 & $12.25^{\mathrm{a}}$ \\
\hline & $E$ & 13 & 12 & 10 & 10 & $11.25^{\mathrm{b}}$ \\
\hline & $\mathrm{F}$ & 13 & 12 & 10 & 9 & $11.00^{\mathrm{b}}$ \\
\hline & Means \pm SD & $13.67^{A}$ & $12.67^{\mathrm{B}}$ & $11.33^{\mathrm{C}}$ & $10.33^{\mathrm{D}}$ & \\
\hline \multirow{7}{*}{$\begin{array}{l}\text { Body\& } \\
\text { Texture } \\
(35)\end{array}$} & $\mathrm{A}$ & 33 & 32 & 31 & 30 & $31.50^{\mathrm{ab}}$ \\
\hline & $B$ & 34 & 33 & 32 & 31 & $32.50^{\mathrm{a}}$ \\
\hline & $\mathrm{C}$ & 33 & 32 & 31 & 30 & $31.50^{\mathrm{ab}}$ \\
\hline & D & 33 & 32 & 31 & 30 & $31.50^{\mathrm{ab}}$ \\
\hline & $E$ & 32 & 30 & 29 & 27 & $29.50^{b}$ \\
\hline & $\bar{F}$ & 31 & 30 & 28 & 26 & $28.75^{\mathrm{C}}$ \\
\hline & Means \pm SD & $32.67^{A}$ & $31.50^{\mathrm{B}}$ & $30.33^{C}$ & $29.00^{\mathrm{D}}$ & \\
\hline \multirow{7}{*}{$\begin{array}{c}\text { Flavor } \\
(50)\end{array}$} & $A$ & 47 & 46 & 45 & 42 & $45.00^{a}$ \\
\hline & B & 48 & 47 & 45 & 42 & $45.50^{a}$ \\
\hline & C & 47 & 46 & 44 & 41 & $44.50^{b}$ \\
\hline & D & 47 & 45 & 44 & 41 & $44.25^{b}$ \\
\hline & $\mathrm{E}$ & 43 & 42 & 40 & 36 & $40.25^{c}$ \\
\hline & $\bar{F}$ & 41 & 39 & 37 & 33 & $37.50^{d}$ \\
\hline & Means \pm SD & $45.50^{\mathrm{A}}$ & $44.17^{\mathrm{B}}$ & $42.50^{C}$ & $39.17^{\mathrm{D}}$ & \\
\hline \multirow{7}{*}{$\begin{array}{l}\text { Total } \\
(100)\end{array}$} & $A$ & 94 & 91 & 88 & 83 & $89.00^{a}$ \\
\hline & B & 96 & 93 & 89 & 84 & $90.50^{\mathrm{a}}$ \\
\hline & C & 94 & 91 & 87 & 82 & $88.50^{b}$ \\
\hline & D & 94 & 91 & 87 & 81 & $88.25^{b}$ \\
\hline & $\mathrm{E}$ & 88 & 84 & 79 & 73 & $81.00^{C}$ \\
\hline & $\mathrm{F}$ & 85 & 81 & 75 & 68 & $77.25^{d}$ \\
\hline & Means \pm SD & $91.33^{A}$ & $88.50^{B}$ & $84.17^{C}$ & $78.50^{D}$ & \\
\hline
\end{tabular}

abcde Letters indicate significant differences between Labneh treatments

${ }^{A B C D}$ Letters indicate significant differences between storage times

It is obvious from Table 5 that the total score gained by the examined Labneh, generally, decreased by advancing the storage period. Such decrease, however, was more noticeable with high concentrations of AWP. Similar results were reported by Salem et al., (2007).

\section{Economic study}

Data in Table 6 show the simple economic analysis for incorporation of AWP in Labneh manufacture. The total prices of Labneh and AWP as well as the reduction in production cost were illustrated in the mentioned table. It could appear that increasing the concentration of AWP added to Labneh raised the net profit. Addition of 5, 10, 15, 20 and $25 \%$ of AWP reduced production cost of Labneh by $4.53,9.06,13.59,18.12$ and $22.66 \%$ respectively. 
Table 6 Economic study of using AWP in making Labneh

\begin{tabular}{|l|c|c|c|c|c|c|c|}
\hline Treatments & $\begin{array}{c}\text { Amount } \\
\text { of } \\
\text { Labneh } \\
\text { (g) }\end{array}$ & $\begin{array}{c}\text { Amount } \\
\text { of AWP } \\
\text { (g) }\end{array}$ & $\begin{array}{c}\text { Price of } \\
\text { Labneh } \\
\text { (LE) }\end{array}$ & $\begin{array}{c}\text { Price } \\
\text { of } \\
\text { AWP } \\
\text { (LE) }\end{array}$ & $\begin{array}{c}\text { Total } \\
\text { Price of } \\
\text { one kg } \\
\text { Labneh } \\
\text { (LE) }\end{array}$ & $\begin{array}{c}\text { Reduction } \\
\text { in } \\
\text { Production } \\
\text { cost (LE) }\end{array}$ & $\begin{array}{c}\text { Reduction in } \\
\text { Production } \\
\text { cost (\%) }\end{array}$ \\
\hline A & 1000 & - & 32.00 & - & 32.00 & - & - \\
B & 950 & 50 & 30.40 & 0.15 & 30.55 & 1.45 & 4.53 \\
C & 900 & 100 & 28.80 & 0.30 & 29.10 & 2.90 & 9.06 \\
D & 850 & 150 & 27.20 & 0.45 & 27.65 & 4.35 & 13.59 \\
E & 800 & 200 & 25.60 & 0.60 & 26.20 & 5.80 & 18.12 \\
F & 750 & 250 & 24.00 & 0.75 & 24.75 & 7.25 & 22.66 \\
\hline
\end{tabular}

Price of 1kg Labneh in Egyptian market 32 LE

Price of $1 \mathrm{~kg}$ AWP Egyptian market 3 LE

It can be concluded that addition of 5,10 and $15 \%$ acid whey protein produced Labneh with acceptable flavour and good appearance and decreased in production cost.

\section{REFERENCES}

Abbas, F. M. and Osman, M. M. (1998). Properties of Labneh like products manufactured using acid and acid-rennet coagulation. Annals Agric. Sci. Moshtohor, 36: 401-411.

Al.Otaibi, M. and El.Demerdash, H. (2008). Improvement of the quality and shelf life of concentrated yoghurt (labneh) by the addition of some essential oils. African Journal of Microbiology Research. 2: 156-161.

American Public Health Association (1992). Standard methods for the examination of dairy products. Amer. Publ. Health Assoc. Inc. $12^{\text {th }}$ ed., New York, USA.

AOAC (2000). Association of Official Analytical Chemists. Official Methods of Analysis. $17^{\text {th }}$ ed, Washington, DC, USA.

Baig, M. I, and Prasad, V. (1996). Effect of incorporation of cottage cheese whey solids and Bifidobacterium bifidum in freshly made yogurt. J. Dairy Res. 63(3) 467- 473.

Belobrajdic, D.; McIntosh, G. and Owens, J. (2004). A high whey protein diet reduces body weight gain and alters insulin sensitivity relative to red meat in Wistar rats. J. Nutrition, 134:1454-1458.

Ceirwyn, S. J., (1995). Analytical Chemistry of Foods. Part I in Book.p.1 English. Published London.

Dave, R. I. and Shah, N. P. (1997). Viability of probiotic bacteria in yoghurts made from commercial starter culture. Int. Dairy J., 7:31-38.

Dave, R. I., and Shah, N. P. (1998). Ingredient supplementation effects on viability of probiotic bacteria in yogurt. J. Dairy Sci. 81:2804-2816.

Dinakar, P. and Mistry, V. V. (1994). Growth and viability of Bifidobacterium bifidum in Cheddar cheese. J. Dairy Sci., 77:2854-2864.

Duncan, D. B. (1955). Multiple Range and Multiple F-test. Biometrics,11:142. 
El-Zeini, H. M.; El-Aasser, M. A.; Anis, S. M. K. and Romeih, E. A. H. (2007): Influence of some processing treatments on chemical composition, rheological properties and micro-structure of cast UF-white soft cheese. Egyptian J. Dairy Sci., 35: 57-72.

Gomes, A. and Malcata, F. X. (1998). Development of probiotic cheese manufacture from goat milk: Response surface analysis via technological manipulation. J Dairy Sci., 81:1492-1507.

Ismail, M. M. (2012). Effect of adding denatured whey proteins to cheese milk or cheese curd on some properties of Ras cheese. Egyptian J. Dairy Sci., 40:59-66.

Ismail, M.; Ammar, E. and El-Metwally, R. (2011). Improvement of low fat Mozzarella cheese properties using denatured whey protein. International J. Dairy Tech., 64(2) 207-217.

Kosikowski, F. V. (1978). Cheese and Fermented Milk Foods. 2nd ${ }^{\text {ed }}$. Cornell Univ. Ithaca, New York.

Ling, E. R. (1963). A Text - Book of Dairy Chemistry. Vol. 2, Practical, $3^{\text {rd }}$ ed., Champan and Hall, London, England.

Mahdian, E. and Tehrani, M. M. (2007). Evaluation the effect of milk total solids on the relationship between growth and activity of starter cultures and quality of concentrated yoghurt. American-Eurasian J. Agric. \& Environ. Sci., 2: 587-592.

Morris, J.G. (2000). The effect of redox potential. In Lund, B.M., Baird-Parker, T.C., \& Gould, G.W. (Ed.), The microbiological safety and quality of food, Vol. 1. (pp. 235-250).

Niness, K.R. (1999). Inulin and oligofructose. What are they? J. of Nutrition, 129(7), 1402-1406.

Parmar, R. (2003). Incorporation of acid whey powders in probiotic yoghurt. M. Sc. Thesis, Major in Biological Sciences, Specialization in Dairy, South Dakota State University, U.S.A.

Punidadas, P., Feirtag, J. and Tung, M. A. (2007): Incorporating whey proteins into Mozzarella cheese. International J. of Dairy Tech. 52(2): $51-52$.

Ravula, R. R. and Shah, N. P. (1999). Survival of microencapsulated L. acidophilus and Bifidobacterium spp. In fermented frozen dairy desserts. J. Dairy Sci. 82:4

Richardson, G.H.(1985): Standard Methods of the Examination of Dairy Products. $15^{\text {th }}$ ed. American Public Health Assocition. Washington, DC.

Salem, Aida S., Salama, Wafaa M., Hassanein, A. M. and El Ghandour, Hanan M. A. (2013). Enhancement of nutritional and biological values of Labneh by adding dry leaves of Moringa oleifera as innovative dairy products. World Applied Sciences Journal 22: 1594-1602

Salem, M. M. E., Abd El-Gawad, Mona A. M., Hassan, Fatma A. M. and Effat, B. A. (2007). Use of synbiotics for production of functional low fat Labneh. Polish J. Food Nutr. Sci. 57:151-159.

SAS (1991). SAS User's guide: statistics. SAS Inst, Inc, Cary, NC.

Tamime, A. Y., and R. K. Robinson. 1999. Yoghurt Science and Technology. 2nd ed. CRC Press, Boca Raton, FL. 
Tashakori, A.; Yasini-Ardakani, S. A. and Daneshi, M. (2013). Effect of whey protein concentrate and cornstarch on chemical, rheological and sensorial properties of white Feta cheese. American J. Food Sci. and Tech. 1: 25-29.

Zheng, W. and Wang, S. Y. (2001). Antioxidant activity and phenolic compounds in selected herbs. J. Agric. Food Chem., 49:5165-5170.

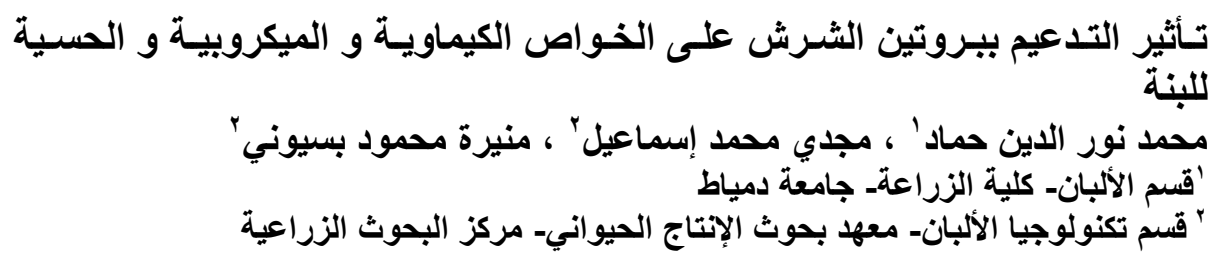

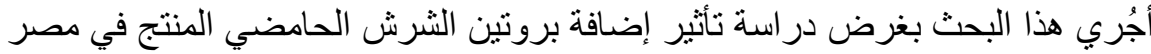

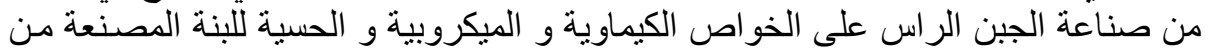

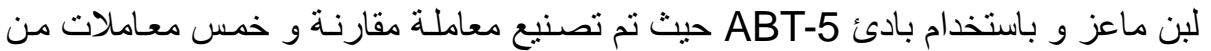

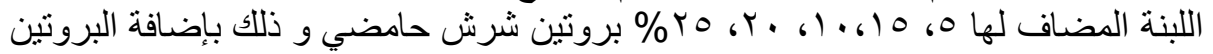

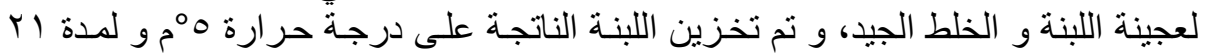

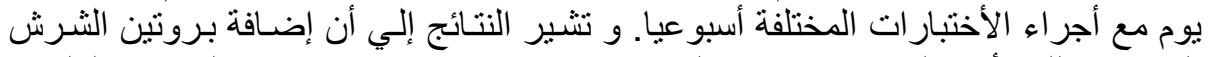

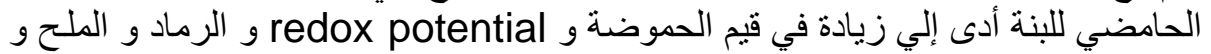

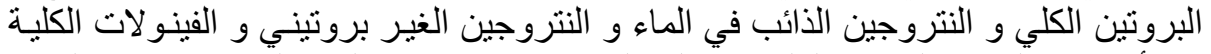

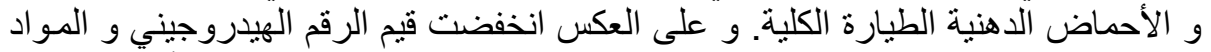

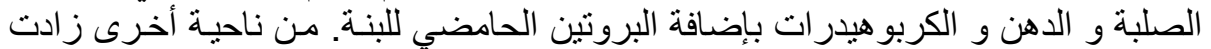

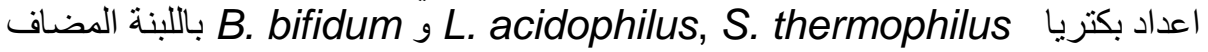

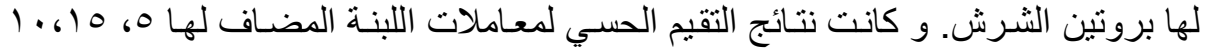



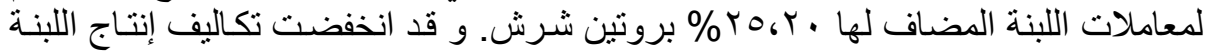
بإضافة بروتين الثرش اللشافئ 